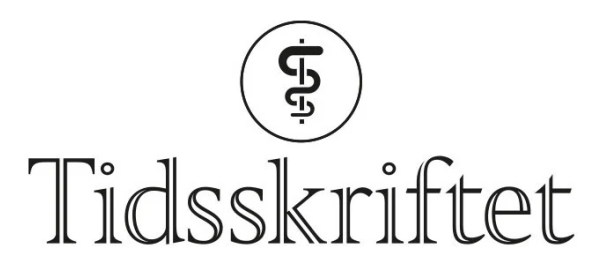

DEN NORSKE LEGEFORENING

\title{
Erik Thorsby
}

\author{
MINNEORD
}

DAGFINN ALBRECHTSEN

PER FAUCHALD

ARNT JAKOBSEN

TORBJØRN LEIVESTAD

PER PFEFFER

GUNNAR SØDAL

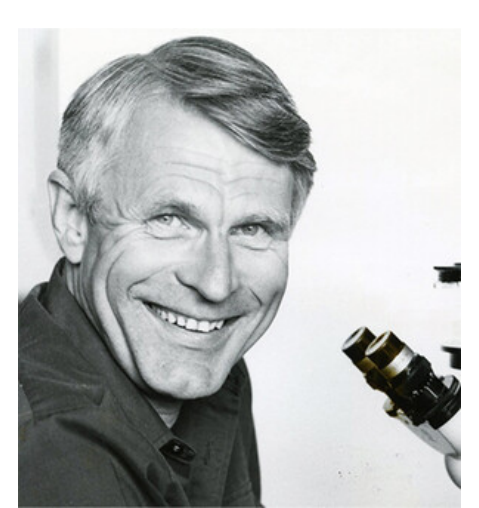

Erik Thorsby, professor i immunologi og en av pionerene i norsk transplantasjonsmedisin, døde 23. mars, 82 år gammel.

Han avla doktorgrad i 1969 etter forskning på HLA-transplantasjonsantigener. I 1970 etablerte han på oppfordring fra Audun Flatmark Vevstypelaboratoriet, hvor han innførte vevstyping og transplantasjonsimmunologi som fagfelt i norsk medisin. Da det ble mulig å finne bedre vevstypeforlikelige givere og mottakere, kunne organtransplantasjon tas $\mathrm{i}$ rutinemessig bruk. Dette bød imidlertid på etiske, juridiske, organisatoriske og $\emptyset$ konomiske utfordringer, som krevde samarbeid og offentlig styring. Sammen med professor Kissmeyer-Nielsen fra Århus tok Erik kontakt med daværende helsedirektør Karl Evang og foreslo opprettelsen av en nordisk ekspertkomité for organtransplantasjon. 
Komiteen ble opprettet i 1968. Erik var medlem frem til 1993. Komiteen fikk støtte fra Nordisk råd til opprettelsen av Scandiatransplant, en organisasjon som samarbeider om organutveksling og forskning internasjonalt, og Norge fikk som et av de første land en transplantasjonslov i 1973 .

Erik kom raskt i fronten av immunologisk forskning både nasjonalt og internasjonalt. Han samarbeidet de følgende tiår tett med oss klinikere i transplantasjonsvirksomheten, også om stamcelletransplantasjon, som han var initiativtaker til i Norge. Hans

forskningsinnsats brakte ham i samarbeid med Nobelprisvinnere ved noen av verdens ledende tranplantasjonssentre, og han var i flere år med i ledelsen av The Transplantation Society. Sammenhengen han i samarbeid med utenlandske kolleger fant mellom HLAantigener og autoimmune sykdommer, som cøliaki, leddgikt, diabetes type 1 og andre, hadde stor klinisk betydning.

Erik var en fremragende organisator, inspirator og pedagog, verdsatt som rådgiver og foredragsholder. Han var en viktig bidragsyter når diskusjonen om og planleggingen av det nye Rikshospitalet kom opp sist på 1980-tallet.

Han ble professor ved Universitetet i Oslo i 1983, var leder av Immunologisk institutt i årene 1998-2006 og dekanus ved Det Medisinske Fakultet i årene 1989-9o. Erik utdannet og veiledet en lang rekke leger og forskere som har gitt viktige bidrag til norsk medisin.

Immungenetikk var viktig i hans forskning, og som 75-åring var han med å publisere studier som tyder på at Påskeøyas første innvandrere kom fra Sør-Amerika, slik Thor Heyerdal hadde hevdet.

Tross alle sine arbeidsoppgaver var det alltid forskningen som stod hans hjerte nærmest, arbeidsom og iderik som han var, like til pensjonering - og enda lenger. Han vil bli savnet. Våre tanker går til Anne, hans ektefelle, støttespiller og legekollega i mer enn 50 år.

Publisert: 25. mai 2021. Tidsskr Nor Legeforen. DOI:10.4045/tidsskr.21.0321

(C) Tidsskrift for Den norske legeforening 2023. Lastet ned fra tidsskriftet.no 26. april 2023. 